\title{
National Characteristic Study of Granados Piano Music
}

\author{
Li Jia' ${ }^{1}, \mathrm{Li} \mathrm{Jia}^{2, *}$ \\ ${ }^{1}$ Department of Piano, Conservatory of Music, Xi'an, Shaanxi, China \\ ${ }^{2}$ College of Music, Shanxi Normal University, Shanxi, China \\ *Corresponding author
}

Keywords: Granados, piano music, nationality, characteristics

\begin{abstract}
Granados is an important representative of Spanish folk music. In his works, can not only see the elements of romanticism, but also the characteristics of Spanish folk music. The organic combination of these two elements makes the piano works created with unique artistic charm. In the development of Spanish piano music culture, Granados is an important force to promote the development of national music. His "Twelve Spanish Dances" and "Goya Painting scene" are the most representative of all works, but also excellent representative works of national music school. The national characteristics of granados piano music were mainly studies in this paper. By analyzing the elements that can reflect the national characteristics in his representative works "Twelve Spanish Dances" and "Goya Painting scene", the important manifestation of the national characteristics of his piano music works were found. They are the reference of Spanish folk song melody, the creative use of Spanish dance rhythm and the imitation of guitar tone.
\end{abstract}

\section{Introduction}

From the aspect of history, Spain is an ancient civilized country that has long history. Spain has the character of cultural combination of Asia, Europe and Africa. The integration of multiple nationalities brought up the richness of Spanish music that forms musical culture of its own features through combining the above three continents' music. Spanish music experienced a flourishing period before the end of $17^{\text {th }}$ century, after a period of stagnation in the $18^{\text {th }}$ century, it was revived again in the second half of the 19th century with many national musical school representatives' likGrandos, Albeniz, Pedregal and Faria sprung up (Feng Xinping, 2012). The music of Granados was not only romantic but full of Spanish national cultural spirit as the main representative of Spanish music. He integrated the unique music elements of the Spanish nation into his creation, and gradually formed his own musical style characteristics through continuous exploration, and made outstanding contributions to the development of Spanish national music. This article attached great importance on exploring the aspects of national characters' reflection of Granados' piano music to better improve the acknowledgement of Spanish national musical culture. 


\section{Spanish Piano Musical Culture}

\subsection{The development of Spanish piano music}

Spanish piano music has strong and unique characteristic and has a certain degree of integration at the same time. Although the development history of Spanish piano music is not very long, a lot of excellent composers and masterpieces emerged. From the aspect of history, the major developing phases of Spanish piano music are as follows.

\subsection{Spanish piano music of Baroque period}

The representative of this period is Antonio Soller who was the most excellent composer of Spain in the $18^{\text {th }}$ century. He composed more than 70 harpsichord sonatas in his lifetime and had prominent contributions to Spanish classicism. Another representative of this period was Lopez whose music style was much more innocent and simple with Spanish cheerful rhythm, inherited of creation mode on the basis of Scalatti. There were no great progress of keyboard music achieved in Spain during the period of 1720 to 1820 although these composer made plenty of works.

\subsection{Spanish piano music of the golden age}

The reviving period of musical composition in Spanish was from the second half of $19^{\text {th }}$ century to the early of $20^{\text {th }}$ century, and the article achievements reached the peakedness at that time. People's thoughts were baptized and liberated under the influence of Renaissance, composers more pursued individualities and themselves in creation. There were both romantic and folk musical genres. During this period, four composers made outstanding contributions to Spanish piano music, namely Albernis, Faria, Granados and Turina (Wang Jianhong, 2010)

\subsection{Spanish piano music in the $20^{\text {th }}$ century}

The Spanish music appeared the characters of diversification in the $20^{\text {th }}$ century, both national civil war and social reforms had great influence on the composition of Spanish piano music. Spanish piano music sprung up many different genres in this period, like nationalism music, expressionism music, New romantic music, neoclassical music and so on. The musical styles of numerous musicians changed as well. At the beginning of the 20th century, Spanish music did not show a strong national character until the end of the Spanish Civil War, nationalist musicians began to devote themselves to composition, and nationalist music gradually became active.

\subsection{Avant-garde piano music in the 20th century}

The World War II caused great damage to the development of the arts, including music, and had an even greater impact on artists. The characteristics of modern music became numerous, complicated and diverse with the impact of avant-garde ideological trend. The avant-garde advocated the collapse of modern musical tonal system. And piano music was groping its way under this background and presented the trend of gradually breaking away from traditional piano music. The composers of this period gradually got rid of the restriction to piano music caused by harmony and melody, constantly explored the rhythm, strength, timbre and playing methods in music, and gradually transformed rhythm into the core of musical composition. 


\section{The characteristics of Spanish piano music}

\subsection{Absorbed some elements from guitars}

Guitars played a huge influence on Spanish music, as well as the Spanish piano musical composition. During the composition period of Spanish piano music, many elements of guitars were absorbed, and writing techniques of guitars were showed.(Zhou Wei, 2013)

\subsection{The influence on piano art caused by Spanish folk singing and dancing factors}

On the one hand, Spanish folk songs have distinctive local characteristics and are full of varieties. The application of Spanish folk's melody makes it easy to identify its Spanish flavor. On the other hand, Spanish dance had major influence on composition of piano arts' composition. Many Spanish pianists use dance rhythms for their piano compositions. The three most commonly used dances include flamenco, tango, and fandango.

\subsection{The influence of French piano art}

In the second half of the $19^{\text {th }}$ century, many native Spanish composers were influenced by France, especially the French Impressionists. Some of the excellent indigenous composers also used some of the Techniques of French Impressionism in their writing. Therefore, many Spanish piano works had both the characteristics of Spanish art and the performance style of French Impressionism.

\subsection{The rich feeling to motherland}

Many compositions express national natural scenery and folk tradition and customs among Spanish piano works. Many compositions were named with Spanish areas and full of Spanish regional style. Some songs absorbed local folk songs and dance elements, and you can feel the beautiful Spanish scenery and strong Spanish national atmosphere from the works.

\section{Granados and his musical compositions}

\subsection{Introduction of Granados}

Granados was born in Lérida, near Barcelona, in 1867. He held concerts in French, New York, Spain and many other countries for many times as a concert performer during his arts period, he made cooperation relations with many musicians as well. As a composer, he wrote many works covering vocal music, chamber music, symphonic poem, opera and piano. As a music educator, he founded the Classical Music Association of Barcelona in 1900 and the Conservatory of Granados in the following year. He presided over educational affairs and cultivated many outstanding musical talents. He is better known for his piano compositions, including "Twelve Spanish Dances", "Goya Painting Scene", "Romantic Scene", "Poetic Waltz", "Six piano pieces based on Spanish popular songs" and so on.

\subsection{Twelve Spanish Dances}

Twelve Spanish Dances was composed from 1892 to 1900 which is one of his most famous works. The work inherited and developed the characteristics of classicism. It was mainly based on traditional piano techniques, but classicism techniques were used in harmony, tonal layout and structural arrangement, or more classical techniques.( Zhao Jingjing, 2011) Twelve Spanish Dances 
embodied the characteristics of romanticism. With the pauses and breathing between phrases like singing, the lyricism of romanticism was fully reflected in the music. The music was composed into a multi-dimensional part through the varied musical texture, which perfectly blended the romantic atmosphere with the elements of national characteristics. The music inherited the romantic tradition and showed a very strong individualistic color.

\subsection{Goya Painting Scene}

In Goya Painting Scene, more Spanish folk music materials were used, and various ballads and dance music were applied to piano works. Goya painted scene reflected the writing techniques of Spanish style, in the light of the commonly used in the Spanish melody mode E mode, fully showed the Spanish music rhythm characteristics on rhythm (Wu Di, 2019), a speed on each piece of every phrase was clearly marked, expression and the power of expression and the strength of the mark were clearly detailed, in terms of strength, the change in strength of each phrase was clearly marked.

\section{The reflection of national characteristics in Granados piano music}

\subsection{The absorb and application of Spanish folk melody}

Most of Granados' musical works adopted different folk music melody of different areas and these elements were integrated with his own compositions to make listeners feel unique charm of Spanish folk music in piano works (Tan Yimin, 2000) .Granados integrated the artistic characteristics of free and changeable rhythm, deeply touching melody and improvisation style of Cante Jondo to the composition of piano music which reflected Spanish nations' characteristics and showed the spiritual pursuit and aesthetic taste of Spanish nations. In his piano musical compositions, Granados also absorbed the rich and colorful folk melodies of various Spanish regions. In other piano works of Granados, the melody of "Tonnadia song" was often used to organically combined with piano works to show the national characteristics of the work (Xiao Yiqing, 2009) .In Granados' composing period of piano musical works, he creatively adopted unique melody of Tonnadia songs to make his musical compositions fully showed passionate and unrestrained character of the Spanish nations (Li Xinrui, 2019).

\subsection{Creative application of Spanish dancing rhythm}

In the creation of Granados piano music, Spanish dancing rhythm was applied in many places, which makes the whole work show full of strong national characteristics. In Spanish local cultures, different regions have their own representative dances, like Flamenco Dance, Hoda Dance, Fandango Dance, Segidia Dance and others, these dances belong to different types with own characteristics that can provide a lot of inspiration for the creative process of musicians. In his composing period, the rhythm characteristics of Flamenco Dance, Hoda Dance and Fandango Dance were applied. In addition, the rhythm characteristics of Tango were often used in Granados' musical works. There was another dancing rhythm was used in Granados' musical works that is Segidia Dance which is a kind of Spanish folk dance with a long history. In the second piece of Goya Painting Scene, Love At the Window, Granados made creative changes to change the triplet in the rhythm of Segidia into penta, which not only enriched the melody and music color of the music, but also showed the dynamic style characteristics of Segidia (Shi Dong, 2020). In the composition of Granados' piano music, a wide range of Spanish dancing rhythms were used, which make the audience have different auditory feelings by changing the rhythm and tone. It is Granados' 
adherence to the spirit of national art and culture that made his piano music works have a different charm.

\subsection{Imitations of guitars' sound pattern}

Gradanos composed extremely characteristic piano musical works by imitating guitar's techniques and sound-types and organically integrating with pianos which was also happens to be the most distinctive and prominent symbol of national characteristics in Granados' works. Firstly, imitations of basic performances techniques to Spanish classical guitars. The two most basic techniques of Spanish classical guitars are Puteado and Rasqueado. Puteado produces clean and ringing sound effects through continuously plucking a monophonic melody on the strings. Granados' piano works imitated many sound-types through monophonic staccato texture. Secondly, Granados used a guitar technique called intrinsic continuance in his piano music. In the guitar playing process, the player keeps the fingers of his left hand on the string, and the sustained tone in the harmony will be like the effect of the keyboard instrument pedal, so as to achieve the effect of internal sustained tone. Moreover, the imitation to the acciaccatura of guitar playing method. Actually, accisccatura is a kind of variation appoggiatura that can be played at any time by overtones of whole tones or semitones and playing as the harmony at the same time. There were many imitations to guitars' acciaccatura sound type that mainly achieved by rapid appoggiatura texture pattern in Granados' musical compositions (Buick, Zhao Gefei, 2018). Finally, quick succession of chords. In the process of playing, it mainly adopts the relaxed and natural hand shape, and moves the strings up and down in the way of Rasqueado. However, in the piano works of Granados, the imitation of rapid continuous chords is mainly through octaves or intensive chords, which is used to express the change of musical mood in transitional phrases, which can promote the emotional development of music very well.

\section{Conclusion}

Granados is the founder of Spanish folk music school, also an important contributor to Spanish folk music as well. He endowed the magnificent and showy piano works with a very romantic ethnic atmosphere, which led to the better development of Spanish folk music. Granados composed many types of musical compositions during his lifetime, but he is best known for his piano works. As a typical representative of Spanish folk music school from the end of the $19^{\text {th }}$ century to the beginning of the 20th century, his piano works showed a very strong ethnic music color, which had an important influence on the development of Spanish piano. In the piano works of Granados, we can see the absorption of folk music melody, the use of Spanish dance rhythm and the imitation of guitar pattern. The study of Granados' piano works and national characteristics also plays a guiding role in the study of Spanish national music school and national characteristics of piano music.

\section{References}

[1] Buick, Zhao Gefei (2018) "Spanish National Style Analysis of Gwanados Goya's Painting Scene” musical composition, 10,133-134.

[2] Didier Frankfurt D. (2011). "Music is like the Tower of Babel --Music and Culture in Europe in the years from 1870 to 1914” (Translated by Guo Changjing, first edition), Fudan University Press, (Year of original publication: 2004)

[3] Feng Xinping (2012), “ Western Musical Brief History (Stamp Sheet) ”, Hefei University of Technology Press.

[4] Li Xinrui(2019), “A Brief Analysis of The Piano Performance Skills and National Characteristics of Granados' Twelve Spanish Dances” (mater's thesis, Suzhou University) 
[5] Shi Dong (2020), "The Narrative Writing Technique of Granados' Love Story”, Chinese Literature and Art, 08, 17-18.

[6] Tan Yimin (2009) “National Style of Granados’ Piano Music”, People’s Music, 06,75-77.

[7] Tang Ruijie(2019), "The National character of Granados' Piano Composition from "Twelve Spanish Dances"” (master's thesis, Shanghai Normal University)

[8] Wang Hongjian(2010), “Art Introduction”, Culture and Art Publishing House.

[9] Wu Di (2019)"There is no better way to shift the atmosphere and change the old habits than to use music to educate. -- Reinterpretation of Granados’ Piano Suite Goya's Painting” Art Science and Technology, 32.111

[10] Xiao Yiqing(2009) “Analysis of Improvisation of Musical Thought in Piano Suite Goya's Painting”, Journal of Xinghai Conservatory of Music, 01-89-93.

[11] Zhao Jingjing(2011), “Analysis of the creative characteristics of Granados' 12 Spanish Dances”, Northern Music, 03, 62-63.

[12] Zhou Wei (2003) “Western Piano Art History” Shanghai Music Publishing House 